\title{
Apoptosis in Lung Development and Neonatal Lung Injury
}

\author{
VERONICA DEL RICCIO, MINKE VAN TUYL, AND MARTIN POST \\ The CIHR Group in Lung Development, Hospital for Sick Children Research Institute, Departments of \\ Pediatrics, Physiology, Laboratory Medicine and Pathobiology, University of Toronto,
} Toronto ON, Canada M5G 1 X8

\begin{abstract}
ABST
A healthy organism maintains an integrated balance between
proliferating, differentiating, and dying cells. Some cells are
irreplaceable, some cells complete their functions and are then
sacrificed, and some cells live a finite lifetime, to be replaced by
another generation. Apoptosis is the last phase of a cell's destiny
and a distinct form of programmed cell death. It is characterized
by loss of cell function and rapid morphological changes, cul-
minating in cell death without inflammation. Apoptosis has been
found to play an important role in the normal regulation of
organogenesis and morphogenesis during development. Apopto-
sis is a fundamental feature in the development of many tissue
systems, including the immune and nervous systems, as well as
in the development of the kidneys and heart. The significance of
apoptosis in lung development has been largely overlooked.
\end{abstract}
Apoptosis, derived from the Greek word for a natural process of leaves falling from trees, is a distinct form of programmed cell death characterized by loss of cell function and rapid morphologic changes, culminating in cell death without inflammation. Apoptosis was first introduced into modern scientific writing by Kerr et al. (1) and has since been found to play an important role in the normal regulation of organogenesis and morphogenesis during development. Apoptosis plays a vital role in the development of many tissue systems, including the immune (2) and nervous systems $(3,4)$, as well as in the development of the kidneys (5) and heart (6). In view of the well-established role of apoptosis in developmental modeling processes, it seems plausible that apoptosis is important for lung development. This review focuses on the importance of mechanotransduction during lung development and its potential role as a stimulus for apoptosis. However, other

Received April 14, 2003; accepted September 12, 2003.

Correspondence: Martin Post, Lung Biology Program, Hospital for Sick Children, 555 University Avenue, Toronto, Ontario, Canada M5G 1X8; e-mail: martin.post@sickkids.ca

Supported by grant (15272) from the Canadian Institutes of Health Research. Dr. M. Post holds a Canadian Research Chair (tier 1) in Respiration.

DOI: 10.1203/01.PDR.0000103930.93849.B2
Physical forces during development may play a role in directing apoptosis in remodeling the lung. This review summarizes current knowledge regarding apoptosis during lung development, with a particular emphasis on the potential role of mechanpotransduction as a stimulus for apoptosis. (Pediatr Res 55: 183-189, 2004)
AEC, alveolar epithelial cell
Abbreviations
TGF- $\boldsymbol{\beta} 1$, transforming growth factor- $\beta 1$
FBM, fetal breathing movements
Apaf-1, apoptotic-protease-activating factor-1
BPD, bronchopulmonary dysplasia
RDS, respiratory distress syndrome

equally important developmental regulators of lung growth and differentiation, including oxygen tension, glucocorticoids, and other hormonal factors, also need to be considered as potential stimulators of apoptosis.

\section{APOPTOSIS AND LUNG DEVELOPMENT}

To provide gas exchange efficiently, the lung undergoes dramatic tissue growth and remodeling both in utero and after birth. Lung development comprises six different stages (Table 1). During the embryonic stage, the lung primordium appears as a ventral diverticulum of the foregut. It separates from the prospective esophagus and elongates caudally. The resulting bud branches for the first time and gives rise to the main bronchi of the left and right lungs. These bronchi divide dichotomously and invade the surrounding mesenchyme, forming the future airways. Looking like a primitive gland, the developing lung enters the pseudoglandular stage. During this period, most of the branching morphogenesis takes place (7). In the subsequent canalicular stage the bronchial tree is established, vascularization increases rapidly, respiratory bronchioli 
Table 1. Lung development and the role of apoptosis

\begin{tabular}{|c|c|c|c|}
\hline Stage & Major events & Role of apoptosis & Reference \\
\hline Embryonic & $\begin{array}{l}\text { Lung anlage appears } \\
\text { Branching morphogenesis starts with extensive } \\
\text { proliferation of epithelial and mesenchymal cells } \\
\text { Few pulmonary vascular connections established }\end{array}$ & $\begin{array}{l}\text { Apoptosis in mesenchyme around branch } \\
\text { points and regions of new lung bud } \\
\text { formation } \\
\text { No epithelial apoptosis }\end{array}$ & 14 \\
\hline Pseudoglandular & $\begin{array}{l}\text { The bronchial airway tree is established by repeated } \\
\text { dichotomous branching } \\
\text { Airways are lined with thick epithelium while } \\
\text { neuroendocrine, ciliated, globular, and Clara cells } \\
\text { start to differentiate }\end{array}$ & $\begin{array}{l}\text { Apoptosis of interstitial tissue contributes to } \\
\text { mesenchymal involution } \\
\text { No epithelial cell apoptosis }\end{array}$ & $9-11$ \\
\hline Canalicular & $\begin{array}{l}\text { Respiratory bronchioli appear } \\
\downarrow \text { interstitial tissue } \rightarrow \text { airway widening } \\
\text { Differentiation of type II into type I cells } \\
\text { Rapid increase of vascular network }\end{array}$ & $\begin{array}{l}\text { Apoptosis of interstitial tissue contributes to } \\
\text { mesenchymal involution and thinning of } \\
\text { the alveolar septa } \\
\uparrow \text { apoptosis of epithelial cells as cell } \\
\text { proliferation } \downarrow\end{array}$ & $9-13$ \\
\hline Saccular & $\begin{array}{l}\text { Terminal airways widen to form saccules } \\
\text { Thinning of interstitium between airspaces } \\
\text { Vascular network expands }\end{array}$ & $\uparrow$ epithelial cell apoptosis & $9-13$ \\
\hline Alveolar & $\begin{array}{l}\text { Extensive alveolar septation; } \uparrow \text { in alveoli } \\
\text { Further thinning of epithelial-endothelial barrier }\end{array}$ & $\begin{array}{l}\text { Transient } \uparrow \uparrow \uparrow \text { in apoptosis at birth } \\
\text { Continuous proliferation of epithelial cells }\end{array}$ & 20,21 \\
\hline Microvascular & $\begin{array}{l}\text { Double capillary layer in alveolar septa is reduced to a } \\
\text { single layer }\end{array}$ & Final $\uparrow$ in apoptosis, to remove excess cells & 20,21 \\
\hline
\end{tabular}

$\uparrow$, increase, $\downarrow$, decrease.

appear, interstitial tissue decreases, and the epithelial barrier thins out as the capillaries begin to lie in close apposition to the epithelium, forming the eventual air-blood barrier (7). By the end of this stage, airway branching is complete and the distal cuboidal epithelium begins to differentiate into alveolar epithelial type II cells (AEC2) and alveolar epithelial type I cells (AEC1), responsible for surfactant production and gas exchange, respectively (7). During the saccular stage of lung development, just before birth, epithelial and air space compartments expand, resulting in terminal clusters of widened spaces called "saccules." The capillary network surrounding the saccules condenses. As a result, the septa now contain two sheets of capillary layers separated by a core of connective tissue. During the period of alveolarization, the gas exchange surface is greatly enhanced by the establishment of secondary septa stemming from the existing primary septa (7). The double capillary layer of the immature alveolar septa is reduced to a single capillary layer during the final developmental phase of microvascular maturation (8).

Apoptotic activity has been observed during all stages of lung development, suggesting its important role during this highly orchestrated process (Table 1). In 1998, two independent studies $(9,10)$ reported the occurrence of apoptosis in fetal lung development. In vivo detection of apoptotic cells is very difficult to assess by morphologic methods because tissue systems have very efficient and rapid clearance mechanisms. However, using three well-established methods to detect apoptosis (light and electron microscopy, the nucleosomal ladder pattern of DNA digestion, and the detection of apoptotic cells in situ by the terminal deoxynucleotidyl transferase-mediated nick-end labeling method), a shift in apoptosis was observed from the mesenchymal tissue layer during the earlier stages of development (9) to both the epithelial and mesenchymal tissue layers during the canalicular stage of development and onward $(10,11)$. Increasing AEC2 apoptosis coincided with a decrease in cell pro- liferation, implicating epithelial apoptosis as a significant contributor of lung remodeling during late gestational development $(12,13)$. Throughout the embryonic stage of lung development, apoptosis was almost exclusively found in the peripheral mesenchyme in regions of new bud formation or in the mesenchyme underlying branch points that are the site of extensive epithelial branching morphogenesis and remodeling of interstitial tissue, allowing room for outgrowth of the lung bud $(10,14)$. It is interesting that mesenchymal cells undergoing apoptosis were intermingled with proliferating mesenchymal cells (14), suggesting that a coordination of these two processes is important in the cell dynamics associated with bronchial branching. Apoptosis during development may be mediated by proapoptotic factors, such as transforming growth factor- $\beta 1$ (TGF- $\beta 1$ ) (15), and antiapoptotic factors, such as IGF-1 (16), nitric oxide $(17,18)$, and secreted apoptosis-related proteins (19), that all are found in the alveolar environment.

After birth, apoptosis emerges as an important process after extensive proliferation and subsequent transformation of primary saccules into functional alveoli $(20,21)$. In rat, during the first 2 wk of life, with distension of alveolar air spaces, fibroblasts and AEC 2 are produced in greater numbers than are actually needed at the end of alveolarization $(21,22)$. Excess of AEC2 is important because they serve as the putative stem cell for AEC1, which line most of the alveolar surface and are critical for the maturation of the air-blood barrier during microvascularization (23). Also, because AEC2 are the producers of surfactant, an excess production ensures sufficiently available surfactant at and just after birth (7). After alveolarization, excess AEC2 decrease in number by differentiating into AEC1 and by apoptosis (20). This wave of apoptosis takes place during the final phase of microvascular maturation, resulting in significant thinning of the thick alveolar septa. There is also a sharp increase in apoptotic activity of pulmo- 
nary rat fibroblasts $(20,21)$. A large proportion of AEC2 cells stain positive for apoptosis during the postnatal period but do not exhibit typical nuclear fragmentation of apoptotic bodies evident in fibroblast cells, suggesting that AEC2 may be cleared by alveolar macrophages in early stages of the apoptotic process (20). Together, these findings support a role for apoptosis in establishing a proper gas exchange surface both in utero and after birth.

\section{BIOPHYSICAL STIMULI OF APOPTOSIS}

In utero, the lung is continuously exposed to a variety of physical forces, including fetal breathing movements (FBM) and tonic distension $(24,25)$. FBM are the characteristic intermittent breathing movements that mechanically stimulate the lung and facilitate fluid pressure changes. This active secretion of fluid by the fetal epithelium sustains a constant pulmonary pressure. FBM have been observed in the fetus starting in the first trimester and increase until term (25). During lung development, as mechanical forces increase via liquid secretion and FBM, proliferation of lung cells increases as well, peaking at the canalicular stage of development and decreasing thereafter $(26,27)$. While proliferation levels are decreasing, apoptotic activity increases $(10,11)$. The same pattern is observed postnatally, during alveolarization, when the lung is experiencing high levels of airspace distension as the infant is breathing on its own. Distension of alveolar air spaces results in proliferation of fibroblast and epithelial cells, followed by apoptosis of these cells $(20,21)$.

Many studies have confirmed cell deformation as the mechanical stimulus that promotes growth of the fetal lung. Stretch induces DNA synthesis and cell division in fetal lung organotypic cultures (28-30), fetal lung fibroblasts $(29,31)$, and fetal AEC2 cells (32). Apoptosis was not described in these proliferation studies because it was not specifically looked at and it is a short-lived event. Apoptosis is a dynamic process that is rapidly completed, often in $<1 \mathrm{~h}$ (33), whereas cell proliferation occurs at a much slower rate (between 12 and $24 \mathrm{~h}$ ) in the developing lung (34). A role for stretch-induced apoptosis in lung development was first suggested by De Paepe et al. (11), who showed that depletion of AEC2 after tracheal ligation in fetal rabbits was at least in part due to an increase in apoptosis. Similarly, 20\% radial elongation stimulated apoptotic activity in primary adult AEC2 (35). However, these studies performed tissue distension under conditions greater than those considered "physiologic" during gestation. Lung fibroblasts from the canalicular stage of development, cultured in a mechanically active environment simulating FBM, showed increased levels of apoptosis, contrary to cells from the pseudoglandular and saccular stages (36). Therefore, mechanical forces seem to stimulate apoptosis of fetal lung fibroblast cells in a time-specific manner and may be involved in the thinning of the periacinar mesenchyme during late fetal lung development. However, it should be mentioned that stretching of isolated cell populations eliminates the effect of epithelialmesenchymal signaling that is vital for proper lung development and that one should be careful in extrapolating in vitro data to in vivo.
Thus, it seems that early in gestation, physical stimuli for proliferation and apoptosis come from a forward-pushing movement of the growing lung bud as well as the forward pushing of the liquid fluid inside the airways (37). The living cells filter the same chemical input from local mechanical deformations and decide to proliferate or die (38), allowing apoptotic and proliferating cells to coexist in the same mesenchymal environment. In addition to these physical stimuli, local growth factor signaling (e.g. fibroblast growth factor-10, sonic hedgehog and bone morphogenetic factor-4) determines the final fate of the cell (39). The tandem of apoptosis and proliferation, early in gestation, is necessary to support a growing lung and to create room needed for growth. Epithelial apoptosis becomes important in the later part of gestation with alveolar growth and seems to be stimulated in utero by increasing FBM and postnatally by airway distension. In addition, FBM may control ongoing mesenchymal condensation via apoptosis.

\section{MECHANOTRANSDUCTION AND APOPTOSIS}

The strong association between the degree of airspace distension and apoptotic activity suggests the existence of a mechanotransduction process through which airspace stretch triggers an apoptotic pathway in epithelial and mesenchymal cells. How distension interacts to produce normal lung growth and by what mechanism this physical stimulus induces proliferation and/or apoptosis of lung cells remains unknown. One possible explanation is through the effect of stretch on cell cycle control. Cells undergoing mitosis and apoptosis share common pathways with the same morphologic and biochemical changes, including rounding of the cell, release of substrate attachments, decrease in cell volume, chromatin condensation, and expression of cell cycle genes $(40,41)$. Apoptosis and proliferation are linked by cell cycle regulators (41), and stimuli such as distension affect both cell proliferation and death. Initially, in the developing lung, mechanical distension may encourage cells to enter the S phase of the cell cycle, leading to increased DNA synthesis and increased levels of proliferation. However, during the later stages of lung development, further increases in distension or a feedback mechanism may interfere with the normal cell cycle, driving cells into the Gap $0\left(\mathrm{G}_{0}\right) / \mathrm{G}_{1}$ phase and eventually to cell death. Fetal AEC2 express several key cyclins and cyclin-dependent kinases, unlike adult AEC2 (42). In rat fetal fibroblasts, isolated at the canalicular stage of lung development and subjected to stretch, cell cycle progression was inhibited and greater numbers of cells were found in the $G_{0} / G_{1}$ phase, whereas fewer cells were found in the $\mathrm{S}$ phase (36).

Cell-cell and cell-matrix contacts are vital for proper lung development and may play an important role in mechanosensing and -transduction. Cells adhere to neighboring cells and to the extracellular matrix via transmembrane receptors of the cadherin and integrin families, respectively. Connections between integrin-rich focal adhesion sites, cytoskeletal filaments, and nuclear scaffolds provide a discrete path that mechanically couples the cytoplasmic portion of integrins to the actin cytoskeleton allowing for mechanical signal transfer (43-45). 
Activation of c-src, a member of the Src family kinases, is a common biochemical response to mechanical stimulation in many cells (Fig. 1). Upon stretch in fetal lung cells, actin filament-associated protein, distributed along the actin filaments, recruits and activates c-src (46). Uni-axial cyclic stretch induces c-src activation and translocation in human endothelial cells via stretch-activated channel activation (47). Furthermore, fibroblast shape is considerably altered in response to stretch, and the signaling mechanism responsible may be via activation of c-src $(48,49)$. Pressure overload in the rat myocardium induced an increase in focal adhesion kinase, which may act in collaboration with c-src, in turn activating signaling pathways involved in multiple cellular processes $(48,50)$. Whether c-src is involved in apoptosis remains to be investigated (Fig. 1). Other signaling pathways involved in apoptosis include the Ras signaling pathway, the mitogen-activated protein kinase pathway, and the phosphatidylinositol 3-kinase pathway, which mediate downstream effects on transcription factors and gene expression $(51,52)$. Furthermore, cells may sense their degree of extension or compression and thus monitor local changes in cell crowding or extracellular matrix compliance and thereby couple changes accordingly. Thus, information from mechanical signals resulting in changes in integrin signaling together with changes in cell shape may be organized by focal adhesions that integrate and orient much of the signal transduction machinery of the cell, resulting in apoptosis or proliferation $(38,53)$.

\section{APOPTOSIS SIGNALING PATHWAY IN FETAL LUNG}

The signaling pathway that mediates apoptosis of fetal epithelial cells is not clear but most likely involves caspasedependent pathways (Fig. 2). One potential candidate is the Fas-Fas ligand (FasL) system, which may play a role in controlling epithelial cell homeostasis (Fig. 1). Fas (CD95/ APO1), a member of the tumor necrosis factor- $\alpha$ receptor family, binds FasL, thereby inducing trimerization of Fas in the target cell membrane. FasL expression has been observed in the adult murine lung and has a spatiotemporal pattern of expression in the developing rabbit lung, where it is highly expressed in AEC2 (54). The time-specific up-regulation of FasL mRNA and protein during development is highly suggestive of a tightly up-regulated transcriptional or posttranscriptional regulation of the FasL gene. Fas is continuously expressed in the fetal lung, and apical Fas receptors are present on bronchiolar Clara cells and AEC2 (54). The up-regulation of FasL expression corresponds with increasing AEC2 apoptosis and maximal airway distension (54), implicating Fas-FasL as a mediator of late-gestational apoptosis, mediated by stretch. The Fas-FasL pathway is pivotal in activating upstream initiator caspases 8 and 10, in turn activating effector caspase 3, culminating in apoptosis. Procaspase- 8 mRNA expression peaks at day 7 of embryonic murine life and remains fairly high onward (55). A homozygous disruption of the mouse caspase 8 gene has been found to be lethal in utero (56), and these mice had impaired heart muscle development and extensive eryth-

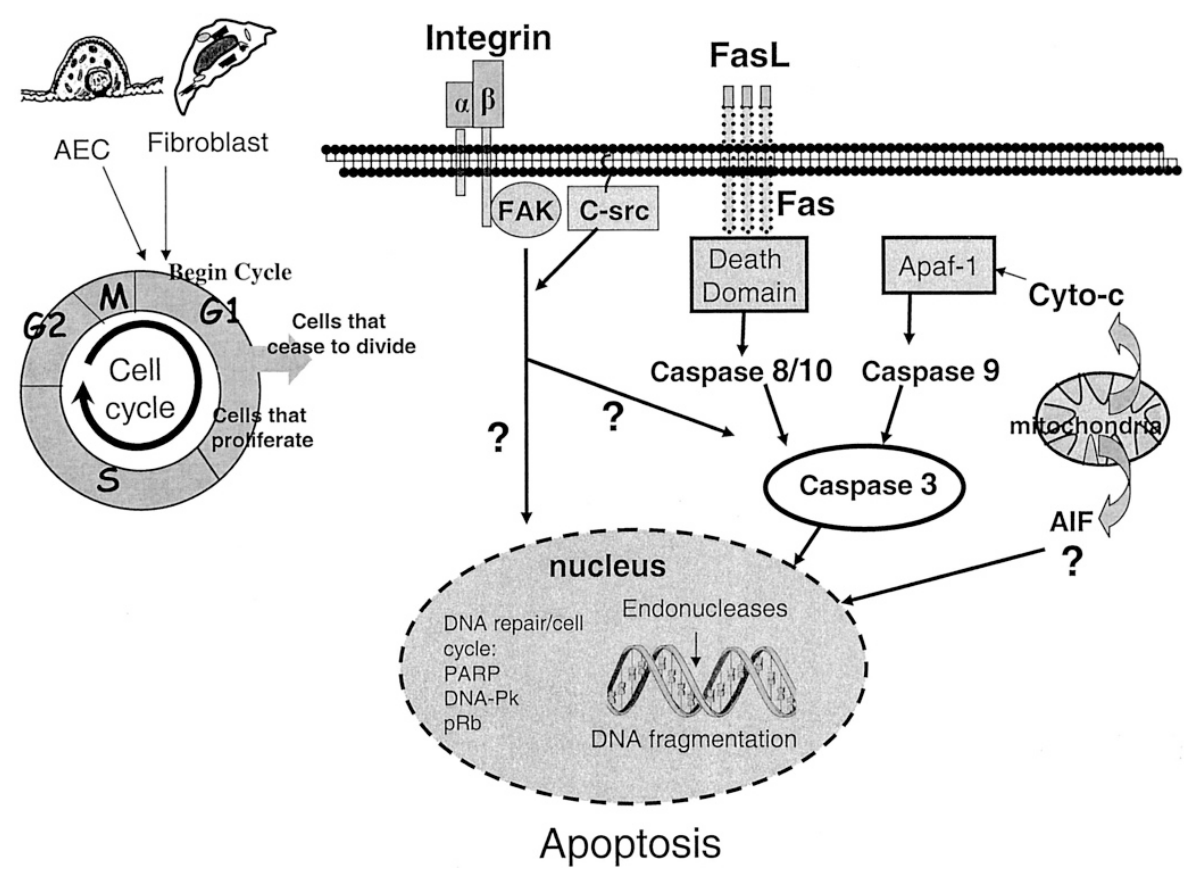

Figure 1. During the $\mathrm{G}_{1}$ phase of the cell cycle, fetal epithelial and fibroblast cells may decide to proliferate or die. In the fetal lung, apoptosis may be orchestrated by cell-matrix interactions (e.g. integrin/focal adhesion kinase/c-src), caspase-dependent pathways (e.g. caspase 8/10 or 9, and 3), or caspaseindependent pathways (e.g. apoptosis-inducing factor). All pathways may coordinate the execution phase of apoptosis by cleaving many key proteins such as nuclear enzyme poly(ADP-ribose) polymerase (PARP), DNA-dependent protein kinase (DNA-pk), retinoblastoma gene (pRb), and degradation of chromosomal DNA. 


\section{Caspase-Dependent Apoptosis}

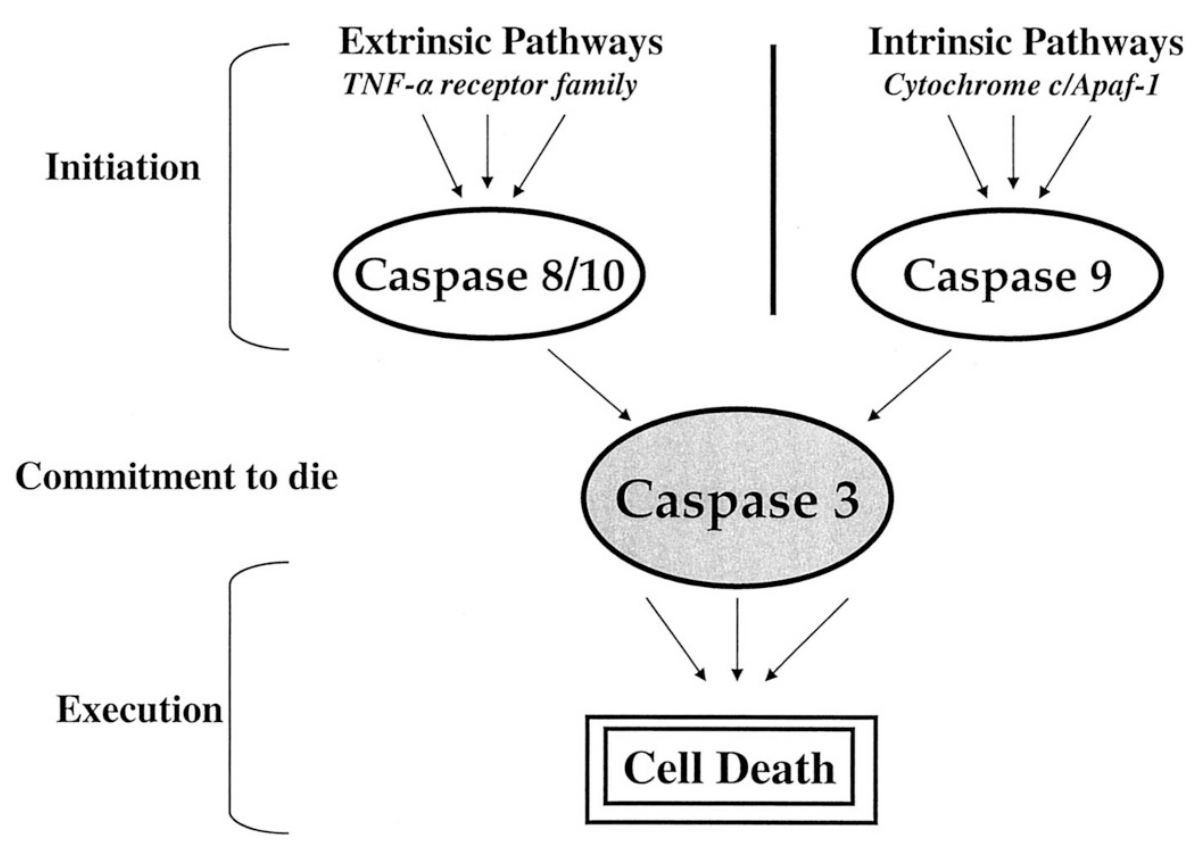

Figure 2. Caspase 3 is the primary executioner caspase and may be activated via two main routes during lung development: 1) intrinsic mitochondrialcytochrome $c$-dependent pathway requiring caspase 9 or 2) an extrinsic pathway initiated by the Fas/FasL system triggering caspase $8 / 10$ activation, in turn activating caspase 3 .

rocytosis in the liver and lungs, perhaps caused by a defect in angiogenesis. However, overall, these mutant mice displayed normal lung development, which questions the role of caspase 8 during fetal lung development. As mentioned earlier, another caspase activated by the Fas-FasL system is caspase 10. Although caspase- 10 is highly expressed in the fetal lung, its exact role in apoptosis remains to be established (57).

It is likely that multiple proapoptotic signaling pathways are involved during development because FasL up-regulation was short lived in fetal rabbit lungs, even though AEC2 apoptosis continued (54). One candidate may be the intrinsic mitochondrial-cytochrome $c$-dependent pathway requiring caspase 9 (Figs. 1 and 2). Cytochrome $c$ seems to act by forming multimeric complexes with apoptotic-protease-activating factor-1 (Apaf-1), which in turn activates caspase 9 (58). Apaf-1 expression is very high in fetal lung (59), correlating with high levels of apoptosis. However, even though both caspase 9- and Apaf-1-deficient mice die around day 16.5 of development, the lung seems unaffected and remarkably normal (60).

The mitochondrial-cytochrome $c$-dependent pathway may be important in mediating apoptosis in fetal lung mesenchymal cells, which do not express Fas or FasL $(36,54)$. Apoptotic activity is relatively high in these cells, and stretch activates caspase 3 activity (36). However, homozygous mice deficient for caspase 3 die during the first weeks after birth with no noticeable lung abnormalities $(61,62)$, suggesting that caspaseindependent pathways may also be involved. One possible candidate involved in the apoptotic mesenchymal reorganization is apoptosis-inducing factor (Fig. 1), which is localized to the mitochondria and released in response to death (63). Apoptosis-inducing factor-dependent cell death is crucial during early mouse morphogenesis, but its role in lung development is not yet known.

\section{APOPTOSIS IN NEONATAL LUNG INJURY}

Bronchopulmonary dysplasia (BPD) describes the postnatal lung pathology caused by a combination of mechanical ventilation and oxygen in preterm infants who have neonatal respiratory distress syndrome (RDS). Although essential to their survival, over time, volume and pressure overload from mechanical ventilation and excess oxygen are injurious to a newborn's lungs, leading to abnormal lung structure and function $(64,65)$. Premature lungs that develop BPD have an early inflammatory reaction and show increased levels of neutrophils, macrophages, and inflammatory cytokines such as IL-8, IL-6, and TGF- $\beta 1$ (66-68). Reparative pneumocyte hyperplasia and proliferation of perivascular smooth muscle cells occurs, leading to pulmonary hypertension and fibroblast hyperplasia $(69,70)$. Furthermore, impaired alveolar development results in alveolar hypoplasia and a decrease in alveolar number and surface area (69-73). The effect of apoptosis on the distortion of the alveolar epithelium in BPD is not clear. Elevated apoptosis was found in AEC2 and bronchiolar cells in infants with BPD (74). Recently, Lukkarinen et al. (75) showed that preterm infants who had RDS and received mechanical ventilation had higher levels of apoptosis particularly in the epithelial cells. Increasing levels of epithelial apoptosis have been observed in neonatal mice exposed to high concentrations of oxygen (76) and in epithelial cells subjected to high levels of mechanical forces (35), two major contributing factors in the development of BPD. It seems that excessive 
apoptosis, above physiologic levels, may worsen the disease, leading to ultrastructural abnormalities, and may be a potential culprit in reducing the number of alveoli characteristic of BPD. Excessive alveolar epithelial cell death could overwhelm the necessary elimination of proliferating mesenchymal and inflammatory cells from the alveolar air space or alveolar walls and further induce the proliferation of lung fibroblasts through the loss of normal inhibition, prolonging inflammation and interfering with re-epithelization, leading to fibrotic overgrowth of lung fibroblasts (77). TGF- $\beta 1$ acts as a chemoattractant for fibroblasts (78) and stimulates immature fibroblast proliferation (79). Furthermore, TGF- $\beta 1$ induces apoptosis in human lung epithelial lines (80) and enhances Fas-FasLmediated apoptosis via caspase 3 activation and downregulation of p21 expression, a cyclin-dependent kinase inhibitor, both in vitro (81) and in vivo (77). Increased levels of TGF- $\beta 1$ are found in airway lavage samples of infants in the early stages of BPD (68). Moreover, high levels of TGF- $\beta 1$ are associated with more severe cases of BPD (68). To date, the expression of FasL in infants with BPD has not been examined. However, given the predominant role of Fas-FasL in adult RDS $(82,83)$ and considering the occurrence of epithelial apoptosis in BPD, one may speculate on its involvement. Therefore, in BPD during tissue remodeling, dysregulation of the TGF- $\beta 1$ pathway may act synergistically with Fasmediated epithelial cell apoptosis during the pathogenesis of pulmonary fibrosis.

Paradoxic is that apoptosis is needed in the repair process of BPD during the fibrotic response. Apoptosis eliminates excess epithelial stem cells needed to reseal the denuded alveolar surface (84) and removes excess proliferating mesenchymal cells (85) and inflammatory cells, such as neutrophils, from the alveolar air space or alveolar walls (86). Failure to clear unwanted cells by apoptosis will prolong the inflammation as a result of the release of their toxic contents. Therefore, apoptosis may have both beneficial and detrimental effects during BPD. Incorrect timing, organization, and location of apoptosis during BPD may result in insufficient growth and disordered maturation of the lung.

\section{CONCLUSION}

The spotlight focusing on the importance of proliferation and differentiation during lung development has shifted to include apoptosis as an important key player. Normal lung development is associated with a progressive increase of apoptosis constantly counteracting proliferation. Intermittent FBM are essential for proper lung development and may act as a potential key regulator of apoptosis. Because prematurely born infants with immature lungs need continuous mechanical ventilation for their survival, the fine balance between growth and apoptosis may be compromised.

\section{REFERENCES}

1. Kerr JF, Wyllie AH, Currie AR 1972 Apoptosis: a basic biological phenomenon with wide-ranging implications in tissue kinetics. Br J Cancer 26:239-257

2. Lagresle C, Bella C, Daniel PT, Krammer PH, Defrance T 1995 Regulation of germinal center B cell differentiation. Role of the human APO-1/Fas (CD95) molecule. J Immunol 154:5746-5756
3. Robinow S, Talbot WS, Hogness DS, Truman JW 1993 Programmed cell death in the Drosophila CNS is ecdysone-regulated and coupled with a specific ecdysone receptor isoform. Development 119:1251-1259

4. Krueger BK, Burne JF, Raff MC 1995 Evidence for large-scale astrocyte death in the developing cerebellum. J Neurosci 15:3366-3374

5. Chandler D, el-Naggar AK, Brisbay S, Redline RW, McDonnell TJ 1994 Apoptosis and expression of the bcl-2 proto-oncogene in the fetal and adult human kidney: evidence for the contribution of bcl-2 expression to renal carcinogenesis. Hum Pathol 25:789-796

6. James TN 1994 Normal and abnormal consequences of apoptosis in the human heart From postnatal morphogenesis to paroxysmal arrhythmias. Circulation 90:556-573

7. Burri PH, Moschopulos M 1992 Structural analysis of fetal rat lung development Anat Rec 234:399-418

8. Burri P 1999 Lung development and pulmonary angiogenesis. In: Gaultier C, Jacques B, Post M (eds) Lung Development. Oxford University Press, New York, pp 122-151

9. Scavo LM, Ertsey R, Chapin CJ, Allen L, Kitterman JA 1998 Apoptosis in the development of rat and human fetal lungs. Am J Respir Cell Mol Biol 18:21-31

10. Kresch MJ, Christian C, Wu F, Hussain N 1998 Ontogeny of apoptosis during lung development. Pediatr Res 43:426-431

11. De Paepe ME, Sardesai MP, Johnson BD, Lesieur-Brooks AM, Papadakis K, Luks FI 1999 The role of apoptosis in normal and accelerated lung development in fetal rabbits. J Pediatr Surg 34:863-870; discussion 870-871

12. De Paepe ME, Johnson BD, Papadakis K, Luks FI 1999 Lung growth response after tracheal occlusion in fetal rabbits is gestational age-dependent. Am J Respir Cell Mol Biol 21:65-76

13. De Paepe ME, Johnson BD, Papadakis K, Sueishi K, Luks FI 1998 Temporal pattern of accelerated lung growth after tracheal occlusion in the fetal rabbit. Am J Pathol 152:179-190

14. Levesque BM, Vosatka RJ, Nielsen HC 2000 Dihydrotestosterone stimulates branching morphogenesis, cell proliferation, and programmed cell death in mouse embryonic lung explants. Pediatr Res 47:481-491

15. Sanchez A, Alvarez AM, Benito M, Fabregat I 1996 Apoptosis induced by transforming growth factor-beta in fetal hepatocyte primary cultures: involvement of reactive oxygen intermediates. J Biol Chem 271:7416-7422

16. Parrizas M, Saltiel AR, LeRoith D 1997 Insulin-like growth factor 1 inhibits apoptosis using the phosphatidylinositol 3'-kinase and mitogen-activated protein kinase pathways. J Biol Chem 272:154-161

17. Kim YM, Talanian RV, Billiar TR 1997 Nitric oxide inhibits apoptosis by preventing increases in caspase-3-like activity via two distinct mechanisms. J Biol Chem 272:31138-31148

18. Shami PJ, Sauls DL, Weinberg JB 1998 Schedule and concentration-dependent induction of apoptosis in leukemia cells by nitric oxide. Leukemia 12:1461-1466

19. Melkonyan HS, Chang WC, Shapiro JP, Mahadevappa M, Fitzpatrick PA, Kiefer MC, Tomei LD, Umansky SR 1997 SARPs: a family of secreted apoptosis-related proteins. Proc Natl Acad Sci U S A 94:13636-13641

20. Schittny JC, Djonov V, Fine A, Burri PH 1998 Programmed cell death contributes to postnatal lung development. Am J Respir Cell Mol Biol 18:786-793

21. Bruce MC, Honaker CE, Cross RJ 1999 Lung fibroblasts undergo apoptosis following alveolarization. Am J Respir Cell Mol Biol 20:228-236

22. Amy RW, Bowes D, Burri PH, Haines J, Thurlbeck WM 1977 Postnatal growth of the mouse lung. J Anat 124:131-151

23. Burri PH 1974 The postnatal growth of the rat lung. 3. Morphology. Anat Rec 180:77-98

24. Vilos GA, Liggins GC 1982 Intrathoracic pressures in fetal sheep. J Dev Physiol 4:247-256

25. Harding R 1997 Fetal pulmonary development: the role of respiratory movements Equine Vet J Suppl Jun:32-39

26. Liu M, Xu J, Souza P, Tanswell B, Tanswell AK, Post M 1995 The effect of mechanical strain on fetal rat lung cell proliferation: comparison of two- and three-dimensional culture systems. In Vitro Cell Dev Biol Anim 31:858-866

27. Nielsen HC, Kirk WO, Sweezey N, Torday JS 1990 Coordination of growth and differentiation in the fetal lung. Exp Cell Res 188:89-96

28. Vandenburgh HH 1992 Mechanical forces and their second messengers in stimulating cell growth in vitro. Am J Physiol 262:R350-R355

29. Xu J, Liu M, Tanswell AK, Post M 1998 Mesenchymal determination of mechanical strain-induced fetal lung cell proliferation. Am J Physiol 275:L545-L550

30. Liu M, Skinner SJ, Xu J, Han RN, Tanswell AK, Post M 1992 Stimulation of fetal rat lung cell proliferation in vitro by mechanical stretch. Am J Physiol 263:L376-L383

31. Bishop JE, Mitchell JJ, Absher PM, Baldor L, Geller HA, Woodcock-Mitchell J, Hamblin MJ, Vacek P, Low RB 1993 Cyclic mechanical deformation stimulates human lung fibroblast proliferation and autocrine growth factor activity. Am J Respir Cell Mol Biol 9:126-133

32. Liu M, Xu J, Tanswell AK, Post M 1993 Stretch-induced growth-promoting activities stimulate fetal rat lung epithelial cell proliferation. Exp Lung Res 19:505-517

33. Jacobson MD, Weil M, Raff MC 1997 Programmed cell death in animal development Cell 88:347-354

34. Uhal BD 1997 Cell cycle kinetics in the alveolar epithelium. Am J Physiol 272:L1031-L1045

35. Edwards YS, Sutherland LM, Power JH, Nicholas TE, Murray AW 1999 Cyclic stretch induces both apoptosis and secretion in rat alveolar type II cells. FEBS Lett 448:127-130

36. Sanchez-Esteban J, Wang Y, Cicchiello LA, Rubin LP 2002 Cyclic mechanical stretch inhibits cell proliferation and induces apoptosis in fetal rat lung fibroblasts. Am J Physiol 282:L448-L456 
37. Schittny JC, Miserocchi G, Sparrow MP 2000 Spontaneous peristaltic airway contractions propel lung liquid through the bronchial tree of intact and fetal lung explants. Am J Respir Cell Mol Biol 23:11-18

38. Chen CS, Mrksich M, Huang S, Whitesides GM, Ingber DE 1997 Geometric control of cell life and death. Science 276:1425-1428

39. Post M, Tanswell KT 2002 Embryonic lung development. In: Hamid Q, Wardlaw AJ (eds) Textbook of Respiratory and Molecular Biology. Martin Dunitz Ltd, London, pp 3-14

40. Meikrantz W, Schlegel R 1995 Apoptosis and the cell cycle. J Cell Biochem 58:160-174

41. King KL, Cidlowski JA 1998 Cell cycle regulation and apoptosis. Annu Rev Physiol 60:601-617

42. Wu F, Buckley S, Bui KC, Warburton D 1995 Differential expression of cyclin D2 and cdc2 genes in proliferating and nonproliferating alveolar epithelial cells. Am J Respir Cell Mol Biol 12:95-103

43. Maniotis AJ, Chen CS, Ingber DE 1997 Demonstration of mechanical connections between integrins, cytoskeletal filaments, and nucleoplasm that stabilize nuclear structure. Proc Natl Acad Sci U S A 94:849-854

44. Wang N, Butler JP, Ingber DE 1993 Mechanotransduction across the cell surface and through the cytoskeleton. Science 260:1124-1127

45. Parsons JT, Martin KH, Slack JK, Taylor JM, Weed SA 2000 Focal adhesion kinase: a regulator of focal adhesion dynamics and cell movement. Oncogene 19:5606-5613

46. Liu M, Qin Y, Liu J, Tanswell AK, Post M 1996 Mechanical strain induces pp60src activation and translocation to cytoskeleton in fetal rat lung cells. J Biol Chem 271:7066-7071

47. Naruse K, Sai X, Yokoyama N, Sokabe M 1998 Uni-axial cyclic stretch induces c-src activation and translocation in human endothelial cells via SA channel activation. FEBS Lett 441:111-115

48. Franchini KG, Torsoni AS, Soares PH, Saad MJ 2000 Early activation of the multicomponent signaling complex associated with focal adhesion kinase induced by pressure overload in the rat heart. Circ Res 87:558-565

49. Sai X, Naruse K, Sokabe M 1999 Activation of pp60(src) is critical for stretchinduced orienting response in fibroblasts. J Cell Sci 112:1365-1373

50. Okuda M, Kawahara Y, Nakayama I, Hoshijima M, Yokoyama M 1995 Angiotensin II transduces its signal to focal adhesions via angiotensin II type 1 receptors in vascular smooth muscle cells. FEBS Lett 368:343-347

51. Ichijo H, Nishida E, Irie $K$, ten Dijke P, Saitoh M, Moriguchi T, Takagi M, Matsumoto K, Miyazono K, Gotoh Y 1997 Induction of apoptosis by ASK1, a mammalian MAPKKK that activates SAPK/JNK and p38 signaling pathways. Science 275:90-94

52. Yao R, Cooper GM 1995 Requirement for phosphatidylinositol-3 kinase in the prevention of apoptosis by nerve growth factor. Science 267:2003-2006

53. Ingber DE, Madri JA, Folkman J 1986 A possible mechanism for inhibition of angiogenesis by angiostatic steroids: induction of capillary basement membrane dissolution. Endocrinology 119:1768-1775

54. De Paepe ME, Rubin LP, Jude C, Lesieur-Brooks AM, Mills DR, Luks FI 2000 Fas ligand expression coincides with alveolar cell apoptosis in late- gestation fetal lung development. Am J Physiol 279:L967-L976

55. Van de Craen M, Van Loo G, Declercq W, Schotte P, Van den Brande I, Mandruzzato S, van der Bruggen P, Fiers W, Vandenabeele P 1998 Molecular cloning and identification of murine caspase-8. J Mol Biol 284:1017-1026

56. Varfolomeev EE, Schuchmann M, Luria V, Chiannilkulchai N, Beckmann JS, Met IL, Rebrikov D, Brodianski VM, Kemper OC, Kollet O, Lapidot T, Soffer D, Sobe T, Avraham KB, Goncharov T, Holtmann H, Lonai P, Wallach D 1998 Targeted disruption of the mouse caspase 8 gene ablates cell death induction by the TNF receptors, Fas/Apo1, and DR3 and is lethal prenatally. Immunity 9:267-276

57. Ng PW, Porter AG, Janicke RU 1999 Molecular cloning and characterization of two novel pro-apoptotic isoforms of caspase-10. J Biol Chem 274:10301-10308

58. Zou H, Li Y, Liu X, Wang X 1999 An APAF-1.cytochrome c multimeric complex is a functional apoptosome that activates procaspase-9. J Biol Chem 274:11549-11556

59. Zou H, Henzel WJ, Liu X, Lutschg A, Wang X 1997 Apaf-1, a human protein homologous to C. elegans CED-4, participates in cytochrome c-dependent activation of caspase-3. Cell 90:405-413

60. Los M, Wesselborg S, Schulze-Osthoff K 1999 The role of caspases in development, immunity, and apoptotic signal transduction: lessons from knockout mice. Immunity 10:629-639

61. Kuida K, Zheng TS, Na S, Kuan C, Yang D, Karasuyama H, Rakic P, Flavell RA 1996 Decreased apoptosis in the brain and premature lethality in CPP32-deficient mice. Nature 384:368-372

62. Woo M, Hakem R, Soengas MS, Duncan GS, Shahinian A, Kagi D, Hakem A, McCurrach M, Khoo W, Kaufman SA, Senaldi G, Howard T, Lowe SW, Mak TW 1998 Essential contribution of caspase 3/CPP32 to apoptosis and its associated nuclear changes. Genes Dev 12:806-819
63. Joza N, Susin SA, Daugas E, Stanford WL, Cho SK, Li CY, Sasaki T, Elia AJ, Cheng HY, Ravagnan L, Ferri KF, Zamzami N, Wakeham A, Hakem R, Yoshida H, Kong YY, Mak TW, Zuniga-Pflucker JC, Kroemer G, Penninger JM 2001 Essential role of the mitochondrial apoptosis-inducing factor in programmed cell death. Nature 410:549-554

64. Martin RJ, Walsh-Sukys MC 1999 Bronchopulmonary dysplasia-no simple solution. N Engl J Med 340:1036-1038

65. Jobe AH, Ikegami M 1998 Mechanisms initiating lung injury in the preterm. Early Hum Dev 53:81-94

66. Bagchi A, Viscardi RM, Taciak V, Ensor JE, McCrea KA, Hasday JD 1994 Increased activity of interleukin-6 but not tumor necrosis factor-alpha in lung lavage of premature infants is associated with the development of bronchopulmonary dysplasia. Pediatr Res 36:244-252

67. Kotecha S, Chan B, Azam N, Silverman M, Shaw RJ 1995 Increase in interleukin-8 and soluble intercellular adhesion molecule-1 in bronchoalveolar lavage fluid from premature infants who develop chronic lung disease. Arch Dis Child Fetal Neonatal Ed 72:F90-F96

68. Lecart C, Cayabyab R, Buckley S, Morrison J, Kwong KY, Warburton D, Ramanathan R, Jones CA, Minoo P 2000 Bioactive transforming growth factor-beta in the lungs of extremely low birthweight neonates predicts the need for home oxygen supplementation. Biol Neonate 77:217-223

69. Husain AN, Siddiqui NH, Stocker JT 1998 Pathology of arrested acinar development in postsurfactant bronchopulmonary dysplasia. Hum Pathol 29:710-717

70. Margraf LR, Tomashefski JF Jr, Bruce MC, Dahms BB 1991 Morphometric analysis of the lung in bronchopulmonary dysplasia. Am Rev Respir Dis 143:391-400

71. Hislop AA, Wigglesworth JS, Desai R, Aber V 1987 The effects of preterm delivery and mechanical ventilation on human lung growth. Early Hum Dev 15:147-164

72. Coalson JJ, Winter VT, Siler-Khodr T, Yoder BA 1999 Neonatal chronic lung disease in extremely immature baboons. Am J Respir Crit Care Med 160:1333-1346

73. Coalson J 2000 Pathology of chronic lung disease of early infancy. In: Bland RD CJ (ed) Pathology of Chronic Lung Disease of Early Infancy. Marcel Dekker, New York, pp $85-124$

74. Hargitai B, Szabo V, Hajdu J, Harmath A, Pataki M, Farid P, Papp Z, Szende B 2001 Apoptosis in various organs of preterm infants: histopathologic study of lung, kidney, liver, and brain of ventilated infants. Pediatr Res 50:110-114

75. Lukkarinen HP, Laine J, Kaapa PO 2003 Lung epithelial cells undergo apoptosis in neonatal respiratory distress syndrome. Pediatr Res 53:254-259

76. McGrath-Morrow SA, Stahl J 2001 Apoptosis in neonatal murine lung exposed to hyperoxia. Am J Respir Cell Mol Biol 25:150-155

77. Hagimoto N, Kuwano K, Miyazaki H, Kunitake R, Fujita M, Kawasaki M, Kaneko Y, Hara N 1997 Induction of apoptosis and pulmonary fibrosis in mice in response to ligation of Fas antigen. Am J Respir Cell Mol Biol 17:272-278

78. Postlethwaite AE, Keski-Oja J, Moses HL, Kang AH 1987 Stimulation of the chemotactic migration of human fibroblasts by transforming growth factor beta. J Exp Med 165:251-256

79. Hill DJ, Strain AJ, Elstow SF, Swenne I, Milner RD 1986 Bi-functional action of transforming growth factor-beta on DNA synthesis in early passage human fetal fibroblasts. J Cell Physiol 128:322-328

80. Yanagisawa K, Osada H, Masuda A, Kondo M, Saito T, Yatabe Y, Takagi K, Takahashi T 1998 Induction of apoptosis by Smad3 and down-regulation of Smad3 expression in response to TGF-beta in human normal lung epithelial cells. Oncogene 17:1743-1747

81. Hagimoto N, Kuwano K, Inoshima I, Yoshimi M, Nakamura N, Fujita M, Maeyama T, Hara N 2002 TGF-beta 1 as an enhancer of Fas-mediated apoptosis of lung epithelial cells. J Immunol 168:6470-6478

82. Matute-Bello G, Liles WC, Steinberg KP, Kiener PA, Mongovin S, Chi EY, Jonas M, Martin TR 1999 Soluble Fas ligand induces epithelial cell apoptosis in humans with acute lung injury (ARDS). J Immunol 163:2217-2225

83. Hashimoto S, Kobayashi A, Kooguchi K, Kitamura Y, Onodera H, Nakajima H 2000 Upregulation of two death pathways of perforin/granzyme and FasL/Fas in septic acute respiratory distress syndrome. Am J Respir Crit Care Med 161:237-243

84. Bardales RH, Xie SS, Schaefer RF, Hsu SM 1996 Apoptosis is a major pathway responsible for the resolution of type II pneumocytes in acute lung injury. Am J Pathol 149:845-852

85. Polunovsky VA, Chen B, Henke C, Snover D, Wendt C, Ingbar DH, Bitterman PB 1993 Role of mesenchymal cell death in lung remodeling after injury. J Clin Invest 92:388-397

86. Meagher LC, Cousin JM, Seck1 JR, Haslett C 1996 Opposing effects of glucocorticoids on the rate of apoptosis in neutrophilic and eosinophilic granulocytes. J Immunol 156:4422-4428 